Article Review

\title{
Karakteristik dan Nilai Gizi Matang Gonad yang Dimiliki Bulu Babi (Echinoidea) di Perairan Habitat Terumbu Karang dan Lamun
}

Fikriyan Mahmud ${ }^{*}$

*Jurusan Manajemen Sumber Daya Perairan, Fakultas Perikanan dan IImu Kelautan, Universitas Negeri Gorontalo. Email: fikriyanmahmud@gmail.com

\section{Introduction}

Indonesia memiliki potensi sumberdaya bulu babi (sea urchin) yang sangat besar. Nane, (2019a) melaporkan bahwa telur bulu babi dapat di konsumsi. Bahkan di beberapa daerah, misalnya di Kepulauan Wakatobi. Pemanfaatan bulu babi telah mengalami overfishing (Nane, 2019c;2019d). Spesies bulu babi yang ada di Kepulauan Indonesia terbilang belum di manfaatkan nilai gizi nya dengan efektif walaupun secara alami mudah di dapatkan belum di manfaatkan secara komersil terutama gonad dari bulu babi, dengan ini menghasilkan suatu usaha yang mendapatkan hasil, tetapi hanya di gunakan sebagai tambahan lauk pauk saja untuk di makan bahkan kebanyakan orang masih takut dengan hewan ini karena memiliki duri di cangkangnya hal itu yang mungkin menyebabkan kenapa di wilayah Indonesia belum saja dimanfaatkan secara terus menerus karena faktor itu hanya sedikit yang mengetauhui dan sedikit pula yang ingin mengambil nya (Zakaria, 2013).

Bulu babi sangat terkenal salah satu produk dari perikanan di perairan laut Indonesia dengan memiliki banyak manfaat bagi kesehatan namun ada beberapa kalangan yang belum tau kandungan gizi yang dimiliki oleh organisme ini salah satu nya memiliki banyak kandungan protein, yang berfungsi memelihara sel-sel jaringan yang 
ada pada tubuh mahkluk hidup yang tak akan bisa digantikan oleh nilai gizi lainnya (Afifudin, 2014). Supono dan Arbi (2010) melaporkan bahwa bulu babi adalah salah satu biota echinodermata yang berpengaruh bagi biota-biota yang habitatnya berada di terumbu karang (Nane et al., 2020). Bulu babi ini mempengaruhi dan menjadi pengendali mikroalga lainnya artinya bulu babi sebagai kunci rantai makanan yang ada di perairan terutama di habitat terumbu karang memungkinkan rantai makanan yang ada di terumbu karang tersebut teratur, artinya baik untuk kelimpahan suatu organisme terumbu karang. Namun juga bisa berkurang jumlahnya bila dilakukan penangkapan secara berlebihan/overfishing (Nane, 2019b; Nane \& Paramata, 2020)

Menurut Moningkey (2010) Menyatakan bahwa cangkang bulu babi yang keras dan tidak dapat dilentukkan dan memiliki tubuh bulat memipih yaitu dari genus echinotrix dengan memiliki tubuh yang keras ini bulu babi memanfaatkan kelebihannya ini dengan berlindung diri dari pasang surutnya air yang hal ini untuk bisa bertahan hidup pada tempat yang disukai yaitu substrat berbatu. Gonad bulu babi memiliki banyak manfaat kaya akan nutrisi didalamnya sehingga bisa dijadikan makanan untuk membantu pertumbuhan kesehatan manusia (Dincer, Cakli, Kilinch, dan Tolasa, 2010). Pendapat lain juga melaporkan bahwa bulu babi juga memiliki tiga komponen utama sebagai penyedia energi dan senyawa yang membantu pertumbuhan sel telur bulu babi yaitu : karbohidrat, lemak, dan protein (McAlister \& Moran, 2012).

Selain itu, dalam cangkang dan duri bulu babi terdapat racun yang bisa dijadikan obat herbal, Racun ini dapat dijadikan obat karena memiliki kandungan senyawa bioaktif yaitu : Serotoin, Glikosida, Steroid, kandungan senyawa inilah yang dapat dijadikan sebagai bahan untuk dijadikan obat (Dahi Jebson dan Louis, 2010). Pendapat lain juga melaporkan bahwa kandungan racun dari cangkang dan duri bulu babi dapat menghambat pertumbuhan bakteri yang ada (Akerina, Nurhayati, dan Suwandi, 2010). 
Faktor musim dan kondisi geografis dapat digunakan tanda atau melihat situasi dan kondisi banyaknya spesies bulu babi yang melimpah dalam memproduksi tingkat kematanggonadnya lebih cepat (Tjendewangi, dan Dahoklory, 2013). Kondisi suatu perairan dan laju pertumbuhan besar kecilnya bulu babi dapat mempengaruhi nilai gizi gonad yang dimiliki oleh bulu babi sehingganya tidak bisa di analisis bulu babi yang besar memiliki gizi gonad yang tinggi karena kemungkinan besar bulu babi yang kecil yang hidup di suatu perairan yang baik di bandingkan bulu babi yang hidup diperairan yang kurang baik yaitu tercemar akan memiliki gizi gonad yang melebihi dari bulu babi besar yang hidup diperairan yang tercemar (silaban, 2012).

Kedalaman suatu perairan juga yang berhubungan erat dengan kelimpahan bulu babi secara umum bulu babi lebih suka dengan perairan yang dangkal daerah interdal, (Firmandana et al, 2014) Melaporkan bahwa menurunnya suatu kelimpahan bulu babi dikarenakan semakin dalam suatu perairan semakin menurun juga kelimpahan bulu babi bahkan semakin dalam perairan tidak dapat dijumpai bulu babi lagi di perairan yang dalam tersebut, karena semakin dalam perairan hal ini berpengaruh dengan bahan organik yang ada di perairan yang dalam tersebut, bulu babi lebih suka berkaitan dengan bahan organik seperti batu karang bulu babi akan melimpah dan menempel di karang tersebut. Kerapatan lamun dengan kelimpahan bulu babi saling berkaitan dipesisir berhubungan dengan rantai makanan, adanya kerapatan lamun tidak berdampak dengan adanya kelimpahan bulu babi ini karena pada dasarnya bulu babi tidak melimpah di kerapatan lamun, bulu babi dominan lebih suka dengan kerapatan lamun yang rendah, walaupun rantai makanan yang saling berkaitan dengan komunitas perairan yang ada didalamnya (Suryanti dan Ruswahyuni, 2014).

Terumbu karang berhubungan erat dengan bulu babi sebagai penyeimbang alam 
bawah laut sehingganya komunitas bulu babi dapat memicu keadaan terumbu karang begitu pula sebaliknya terumbu karang dapat memicu pertumbuhan bulu babi karena bulu babi identik dengan menempel atau lebih suka dibebatuan, ditemukan bahwa pemulihan populasi bulu babi yang tidak terlalu melimpah membutuhkan waktu kurang lebih 10 tahun dengan adanya terumbu karang sebagai keterkaitan dengan bulu babi itu sendiri (Darsono dan Toso, 2010). Faktor yang mempengaruhi kadar lemak yang tinggi yaitu di pengaruhi oleh bulu babi itu sendiri jika terlalu besar artinya memilliki gonad yang besar jika kecil artinya memiliki gonad yang kecil juga, jadi pada dasarnya makanan yang akan mempengaruhi pertumbuhan sekaligus mememiliki banyak kandungan lemak (Tupan dan Silaban, 2017).

Menurut Purwaningsih (2012) Kadar abu yang berbeda pada setiap spesies dikarenakan oleh spesies itu sendiri setiap mahkluk hidup organisme ini pasti memiliki kemampuan yang berbeda-beda dalam mengabsorsi logam, sehingga logam yang ada di suatu perairan yang berbeda pasti makanannya pun berbeda sehingga logam yang ada pada makanan itu yang di produksi kedalam tubuh berbeda. Kadar asam Glutamat yang tinggi pada gonad bulu babi akan memberikan rasa enak yang gurih bila dimasak untuk dimakan. Sulistyawibowo et al, (2013) melaporkan bahwa glutamat ini berfungsi menjalankan fungsi otak karena asam amino ini, dapat digunakan sebagai suplemen herbal untuk tubuh dapat membentuk pertumbuhan dan perkembangan otot baik di gunakan oleh manusia yang membutuhkan kebutuhan khusus terutama dalam kerja keras yang mengakibatkan kerusakan otot dengan adanya glutamate ini bisa memulihkan pertumbuhan dan perkembangan bagi tubuh. Perbedaan kadar protein yang didapat dari hasil penelitian bulu babi dikarenakan oleh habitat dan jenis dari bulu babi yang berbeda ini, Tupan dan Silaban, (2017) Melaporkan bahwa 
kandungan gizi protein di dalam bulu babi itu tergantung besar gonadnya dan adapun yang berwarna kuning terbilang memiliki banyak kandungan protein yang melimpah.

\section{Conclusion}

Kesimpulan yang bisa dimbil dari tulisan diatas bahwa Bulu babi adalah salah satu biota echinodermata yang berpengaruh bagi biota-biota yang habitatnya berada di terumbu karang, karena bulu babi mempengaruhi dan pengendali mikroalga lainnya artinya bulu babi sebagai kunci rantai makanan yang ada di perairan terutama di habitat terumbu karang memungkinkan rantai makanan yang ada di terumbu karang tersebut teratur, artinya baik untuk kelimpahan suatu organisme terumbu karang, Bulu babi memiliki cangkang dan duri, hal ini memiliki banyak gizi pada gonadnya yang bisa memberikan kesehatan bagi tubuh.

\section{References}

Hadinoto, S., Sukaryono, I. D., \& Siahay, Y. (2017). Kandungan Gizi Gonad dan Aktivitas Antibakteri Ekstrak Cangkang Bulu Babi (Diadema setosum). Jurnal Pascapanen dan Bioteknologi Kelautan dan Perikanan, 12(1), 71-78.

Lawi, Y. S. A., Amir, A., \& Abd Jabbar, F. B. (2019). Indeks Kematangan Gonad Dan Diameter Telur Landak Laut Tripneustes Gratilla Di Pulau Barrang Lompo Sulawesi Selatan. Siganus: Journal of Fisheries And Marine Science, 1(1), 1015.

Nane, L. (2019a). Efisiensi Mesin Teknologi Sapurata Dalam Mengoptimalisasi Produksi Inovasi Pangan Kukure Di Pulau Barrang Lompo, Makassar. https://doi.org/10.31230/osf.io/q8spg 
Nane, L. (2019b). Impact of overfishing on density and test-diameter size of the sea urchin Tripneustes gratilla at Wakatobi Archipelago, south-eastern Sulawesi, $\begin{array}{lll}\text { Indonesia. } & \text { BioRxiv, } & 727271 .\end{array}$ https://www.biorxiv.org/content/10.1101/727271v1

Nane, L. (2019c). Sea Urchin Sustainability Studies Based on Dimension Biology, Ecology and Technology at Around of Tolandono Island and Sawa Island at Wakatobi Conservation Area. https://doi.org/10.31230/osf.io/4whz6

Nane, L. (2019d). Studi Keberlanjutan Perikanan Landak Laut Berdasarkan Dimensi Biologi, Ekologi Dan Teknologi Di Sekitar Pulau Tolandono Dan Pulausawa Kawasan Konservasiwakatobi [Skripsi, Universitas Hasanuddin]. https://Marxiv.Org/9zdvr/

Nane, L., \& Paramata, A. R. (2020). Impact of Overfishing on Density and Test-Diameter Size of the Sea Urchin Tripneustes gratilla at Wakatobi Archipelago, SouthEastern Sulawesi, Indonesia. ILMU KELAUTAN: Indonesian Journal of Marine Sciences, 25(2), 53-56. https://doi.org/10.14710/ik.ijms.25.2.53-56

Nane, L., Baruadi, A. S. R., \& Mardin, H. (2020). The density of the blue-black urchin Echinotrix diadema (Linnaeus, 1758) in TominiBay, Indonesia. Tomini Journal of Aquatic Science, 1(1), 16-21. https://doi.org/10.37905/tjas.v1i1.5939

Padang, A., Nurlina, N., Tuasikal, T., \& Subiyanto, R. (2019). Kandungan Gizi Bulu Babi (Echinoidea). Agrikan: Jurnal Agribisnis Perikanan, 12(2), 220-227.

Ristanto, A., Setyawati, T. R., \& Yanti, A. H. Komposisi Jenis Bulu Babi (Kelas: Echinoidea) di Daerah Intertidal Pulau Lemukutan Kabupaten Bengkayang. Protobiont, 6(1).

Setyawan, B., Sulardiono, B., \& Purnomo, P. W. (2014). Kelimpahan Bulu Babi (Sea Urchin) pada Ekosistem Terumbu Karang dan Ekosistem Padang Lamun di Pulau Panjang, Jepara. Management of Aquatic Resources Journal, 3(2), 74-81. Sulistiawan, R., Solichin, A., \& Rahman, A. (2019). Hubungan Kerapatan Lamun Dengan Kelimpahan Bulu Babi (Echinoidea) Di Pantai Pancuran Taman Nasional Karimunjawa, Jepara The Correlation Of Seagrass Density With Abundance Of Sea Urchins (Echinoidea) In Pancuran Beach Karimunjawa National Park, Jepara. Management of Aquatic Resources Journal, 8(1), 28

Suseno, S. H., \& Jacoeb, A. M. (2014). Profil Asam Lemak Dan Asam Amino Gonad Bulu Babi. Jurnal Pengolahan Hasil Perikanan Indonesia, 17(1). 
Tupan, J., \& br Silaban, B. (2017). Karakteristik Fisik-Kimia Bulu babi Diadema setosum dari beberapa Perairan Pulau Ambon. Triton, 13(2), 71-78.

Yudasmara, G. A. (2013). Keanekaragaman Dan Dominansi Komunitas Bulu Babi (Echinoidea) Di Perairan Pulau Menjangan Kawasan Taman Nasional Bali Barat. JST (Jurnal Sains dan Teknologi), 2(2).i 